\title{
OPHTHALMOLOGIC EVALUATION IN PROFESSIONAL MALE SOCCER PLAYERS IN BRAZIL
}

\author{
AVALIAÇÃO OFTALMOLÓGICA EM JOGADORES PROFISSIONAIS DE FUTEBOL NO BRASIL
}

Original Article

EVALUACIÓN OFTALMOLÓGICA EN JUGADORES PROFESIONALES DE FÚTBOL EN BRASIL

ARTIGO ORIGINAL

Artículo Original

Aline Sutili Toledo'

(Physician)

Gustavo Gonçalves Arliani² (Physician)

Paulo Henrique Schmidt Lara² (Physician)

Rodrigo Kallas Zogaib ${ }^{3}$

(Physician)

Moisés Cohen ${ }^{2}$

(Physician)

Benno Ejnisman²

(Physician)

1. Universidade Federal de São Paulo (UNIFESP), Department of Ophthalmology, SP, Brazil. 2. Universidade Federal de São Paulo (UNIFESP), Sports Traumatology Center, Department of Orthopedics and Traumatology, SP, Brazil.

3. Santos Futebol Clube, Santos, SP, Brazil.

\section{Correspondence:}

Paulo Henrique Schmidt Lara Rua Estado de Israel, 636, Vila Clementino, São Paulo, SP, Brazil. 04022-001.phslara@gmail.com

\section{ABSTRACT}

Introduction: Soccer is the most popular sport in Brazil and worldwide, but there is insufficient data on the eye health of soccer players, and eye conditions may affect the well-being and performance of these athletes. Objective: To perform an ocular evaluation of a representative sample of professional soccer players from Brazil. Methods: This was a cross-sectional study conducted over four consecutive years (2009-2012) at a single professional soccer club in Brazil. The ophthalmology evaluation was performed by the same ophthalmologist in each sample. Prior to the ophthalmology evaluation, all participants filled out a questionnaire to provide the following demographic data: age, position, use of contact lenses or ophthalmic drugs, symptoms, previous ocular surgery, and date of the last ophthalmology evaluation. Visual acuity, intraocular pressure (IOP) and color vision were tested during the ophthalmologic examination, and ophthalmoscopy and biomicroscopy exams were performed. Results: One hundred and twenty bilateral ophthalmology evaluations were performed in 84 professional soccer players between 2009 and 2012. Pinguecula and pterygium were the most common conditions found in the athletes' biomicroscopy exams, corresponding to 63\% (38/60) and 17\% (10/60) of abnormalities, respectively. In the contrast sensitivity evaluation, only one athlete was color blind. No significant associations were found between the position of the athlete and the results of the biomicroscopy and ophthalmoscopy exams. Conclusion: Despite the high prevalence of abnormalities found in the ophthalmology evaluation, most refractive abnormalities did not require correction, and the biomicroscopy abnormalities were mostly benign. Level III; Study of non-consecutive patients.

Keywords: Soccer; Injuries; Eye; Athletes.

\section{RESUMO}

Introdução: O futebol éo esporte mais popular no Brasil e no mundo, mas há dados insuficientes quanto à saúde ocular dos jogadores, o que pode exercer um impacto no bem-estar e desempenho desses atletas. Objetivo: Realizar uma avaliação oftalmológica em uma amostra significativa de jogadores profissionais de futebol do Brasil. Métodos: Esse foi um estudo transversal realizado durante quatro anos consecutivos (2009-2012) em um único clube de futebol profissional no Brasil. A avaliação oftalmológica foi realizada pelo mesmo médico oftalmologista em cada amostra. Antes da avaliação oftalmológica, todos os participantes preencheram um questionário que fornecia os seguintes dados: idade, posição, uso de lentes de contato ou medicamentos oftalmológicos, sintomas, cirurgia oftalmológica prévia e data da última avaliação oftalmológica. Durante o exame oftalmológico, foram avaliados: acuidade visual, pressão intraocular (PIO) e visualização das cores, além disso, também foram realizados exames de oftalmoscopia e biomicroscopia. Resultados: Cento e vinte avaliações oftalmológicas bilaterais foram realizadas em 84 jogadores profissionais de futebol entre 2009 e 2012. Pinguécula e pterígio foram as condições mais comuns encontradas na biomicroscopia dos atletas, correspondendo a 63\% (38/60) e 17\% (10/60) das alterações, respectivamente. Na avaliação do senso cromático, apenas um atleta era daltônico. Não houve associações significativas entre a posição dos atletas e os resultados da biomicroscopia e oftalmoscopia. Conclusão: Apesar da alta prevalência de alterações encontradas na avaliação oftalmológica, a maioria das alterações refrativas não exigiram correção e as alterações na biomicroscopia eram na maioria das vezes benignas. Nível de evidência III; Estudo de pacientes não consecutivos.

Descritores: Futebol; Lesões; Olho; Atletas.

\section{RESUMEN}

Introducción: El fútbol es el deporte más popular en Brasily en el mundo, pero hay datos insuficientes cuanto a la salud ocular de los jugadores, lo que puede ejercer un impacto en el bienestar y desempeño de esos atletas. Objetivo: Realizar una evaluación oftalmológica en una muestra significativa de jugadores profesionales de fútbol de Brasil. Métodos: Este fue un estudio transversal realizado durante cuatro años consecutivos (2009-2012) en un único club de fútbol profesional en Brasil. La evaluación oftalmológica fue realizada por el mismo médico oftalmólogo en cada muestra. Antes de la evaluación oftalmológica, todos los participantes Ilenaron un cuestionario que proporcionaba los siguientes datos: edad, posición, uso de lentes de contacto o medicamentos oftalmológicos, síntomas, cirugía oftalmológica previa y fecha de la última evaluación oftalmológica. Durante el examen oftalmológico, fueron evaluados: acuidad visual, presión intraocular (PIO) y visualización de los colores. Además, también fueron realizados exámenes de oftalmoscopia y biomicroscopía. Resultados: Fueron realizadas ciento veinte evaluaciones oftalmológicas bilaterales en 84 jugadores profesionales de fútbol entre 2009y 2012. Las condiciones más comunes encontradas en la biomicroscopía de los atletas fueron pinguécula y pterigium, correspondiendo a 63\% (38/60) y 17\% (10/60) de las alteraciones, respectivamente. En la 
evaluación del sentido cromático, sólo un atleta era daltónico. No hubo asociaciones significativas entre la posición de los atletas y los resultados de la biomicroscopía y oftalmoscopia. Conclusión: A pesar de la alta prevalencia de alteraciones encontradas en la evaluación oftalmológica, la mayoría de las alteraciones refractivas no exigieron correccióny las alteraciones en la biomicroscopía eran en la mayoría de los casos benignas. Nivel de evidencia III; Estudio de pacientes no consecutivos.

Descriptores: Fútbol; Lesiones; Ojo; Atletas.

\section{INTRODUCTION}

Football is the most popular sport in Brazil and worldwide. Specifically, there are more than 240 million amateur football players and at least 200,000 professional players on the planet. Despite the huge increase in women's football in recent years, $80 \%$ of football players are still men., ${ }^{1,2}$

The death of several athletes during football matches due to heart problems has caused great concern and prompted discussion in both FIFA (Fédération Internationale de Football Association) and medical societies. In fact, a survey conducted by the former indicated an average rate of one sudden death per month during football matches in the last 10 years. ${ }^{3}$ These data demonstrated the importance of physical pre-participation assessments in football. Such assessments are primarily aimed at detecting conditions that may limit athlete participation or expose athletes to risk of injury, illness, or even death during sports. These assessments also aim to evaluate athletes' overall health situation, inform medical advice, and determine physical and performance parameters. ${ }^{4}$

Mirabelli et al. ${ }^{5}$ demonstrated that the most common abnormal findings during these assessments were elevated systemic blood pressure and ophthalmic problems. In the vast majority of cases, these ophthalmological changes do not prevent or exclude athletes from football practice. However, they can directly affect the quality of life and performance of the players. ${ }^{6,7}$

Our review of the literature found no studies on ophthalmological evaluation focused on professional football exclusively. Almost all relevant studies are related to traumatic eye injuries in this sport and visual evaluations in other sports., ${ }^{8,9}$ Therefore, as the ophthalmological health of football players is currently unclear, and in view of the potential impact on athletes' well-being and performance, the objective of this study was to perform ocular evaluation of a representative sample of professional football players from Brazil.

\section{MATERIAL AND METHODS}

This was a cross-sectional study conducted during 4 consecutive years (2009-2012) in a single professional football club in Brazil. The study was approved by our Ethics and Research Committee (56723616.3.0000.5505), and all players agreed to participate in the study by completing an informed consent form. All professional team players who were over 18 years of age agreed to participate in the study.

The ophthalmologic evaluation was performed by the same specialist physician in each sample. Prior to the ophthalmological examination, all participants filled out a questionnaire to provide the following data: age, position, use of contact lenses or ophthalmological drugs, symptoms, previous ophthalmological surgery, and date of the last ophthalmological evaluation. Visual acuity, intraocular pressure (IOP), fundoscopy, biomicroscopy, and colour vision were measured during the ophthalmologic examination.

Although 25 athletes had previously undergone ophthalmological evaluation during four years of the study period, the descriptive analyses were conducted in the sample of 120 evaluations, because the results may have been differed over time. The qualitative characteristics of the players were described using absolute and relative frequencies, and the quantitative characteristics were described using summary measures (mean, standard deviation, median, minimum and maximum or quartiles). The athletes'age and visual acuity were correlated using a model of generalised estimation equations (GEEs). The athletes' positions were associated with fundoscopy and biomicroscopy using multiple comparisons among the estimated proportions. A p-value < 0.05 was considered significant in all analyses. Statistical analysis was performed using SPSS 18.0 software.

\section{RESULTS}

120 bilateral ophthalmological evaluations were performed in 84 professional football players between 2009 and 2012. Of the 84 athletes, 70\% (59) only underwent one evaluation, 18\% (15) attended two evaluations, eight \% (7) were given three evaluations and only four \% (three) underwent four evaluations.

Table 1 shows the descriptive analysis of age, position, and other variables of the 120 ophthalmological evaluations.

We found changes in 60 eyes in the biomicroscopy. Pinguecula and pterygium were the most common conditions, corresponding, to $63 \%$ $(38 / 60)$ and $17 \%(10 / 60)$ of the changes, respectively. In the evaluation of the chromatic sense, only one athlete was colour blind.

Table 2 shows the descriptive analysis of the age of the athletes in terms of the visual acuity results in both eyes. No significant relationship was found between visual acuity and the athletes' age ( $p=0.752)$.

Finally, no significant associations were found between the position of the athlete and the results of the biomicroscopy and fundoscopy evaluations. (Table 3)

\section{DISCUSSION}

Pre-participation assessment is most commonly performed annually among football players, and the best time for this assessment is 6 weeks before the preseason, which allows for correction of any identified problems., ${ }^{4,10}$

Lombardo et al. ${ }^{4}$ argued that an ophthalmological assessment should be performed during this pre-participation assessment, and that the symmetry of the pupils should be evaluated, as this can be used to determine whether the athlete has suffered head trauma. The same researchers reinforced the importance of evaluating changes such as subluxation of the lens, severe myopia, retinal detachment, and strabismus, which are associated with Marfan syndrome.

Visual deficiencies can put athletes at risk while performing physical activity. Lehmann et al. ${ }^{11}$ argued that the Snellen test should be performed on all athletes before they participate in sports, as did Miller et al. ${ }^{12}$ The tests should be performed with the glasses or contact lenses that the athlete uses during their respective sport, and a visual acuity better than 20/40 is a prerequisite for safe sports participation. Like Lombardo et al. ${ }^{4}$, these authors also reinforced the importance of assessing pupil symmetry, which can indicate traumatic brain injury.

A study by Needleman et al. ${ }^{13}$ showed that professional football players in England have poor dental health, which interferes with their quality of life and sports performance. These authors advocated screening for dental problems among athletes. We believe that this is also worthwhile in the case of ophthalmological screening, since some ophthalmological alterations lead to deterioration in quality of life and sports performance. 
Table 1. Descriptive analysis of ophthalmologic evaluations.

\begin{tabular}{|c|c|}
\hline Age (years) & \\
\hline mean (SD) & $23.6(4.2)$ \\
\hline minimum - maximum & $18-35$ \\
\hline \multicolumn{2}{|l|}{ Evaluation year } \\
\hline 2009 & $26(21.7)$ \\
\hline 2010 & $31(25.8)$ \\
\hline 2011 & $25(20.8)$ \\
\hline 2012 & $38(31.7)$ \\
\hline \multicolumn{2}{|l|}{ Position } \\
\hline Goalkeeper & $14(11.7)$ \\
\hline Full-back & $16(13.3)$ \\
\hline Defender & $25(20.8)$ \\
\hline Midfielder & $46(38.3)$ \\
\hline Forward & $19(15.8)$ \\
\hline \multicolumn{2}{|l|}{ Last evaluation (years) } \\
\hline Less than 1 & $63(52.5)$ \\
\hline 2 & $11(9.2)$ \\
\hline More than 3 & $14(11.6)$ \\
\hline Never performed & $32(26.7)$ \\
\hline \multicolumn{2}{|c|}{ Previous ophthalmological surgery } \\
\hline No & $120(100.0)$ \\
\hline \multicolumn{2}{|l|}{ Contact lenses use } \\
\hline Yes & $4(3.3)$ \\
\hline No & $116(96.7)$ \\
\hline \multicolumn{2}{|c|}{ Ophthalmological drugs use } \\
\hline Yes & $4(3.3)$ \\
\hline No & $116(96.7)$ \\
\hline \multicolumn{2}{|c|}{ Refractive evaluation - Right eye } \\
\hline Normal & $84(70.0)$ \\
\hline Altered & $36(30.0)$ \\
\hline \multicolumn{2}{|c|}{ Refractive evaluation - Left eye } \\
\hline Normal & $84(70.0)$ \\
\hline Altered & $36(30.0)$ \\
\hline \multicolumn{2}{|c|}{ Intraocular Pressure - Right eye } \\
\hline Normal & $120(100.0)$ \\
\hline \multicolumn{2}{|c|}{ Intraocular Pressure - Left eye } \\
\hline Normal & $119(99.2)$ \\
\hline Altered & $1(0.8)$ \\
\hline \multicolumn{2}{|l|}{ Fundoscopy - Right eye } \\
\hline Normal & $120(100.0)$ \\
\hline \multicolumn{2}{|l|}{ Fundoscopy - Left eye } \\
\hline Normal & $120(100.0)$ \\
\hline \multicolumn{2}{|c|}{ Biomicroscopy - Right eye } \\
\hline Normal & $92(76.7)$ \\
\hline Altered & $28(23.3)$ \\
\hline \multicolumn{2}{|l|}{ Biomicroscopy - Left eye } \\
\hline Normal & $88(73.3)$ \\
\hline Altered & $32(26.7)$ \\
\hline \multicolumn{2}{|l|}{ Chromatic Sense } \\
\hline Normal & $119(99.2)$ \\
\hline Altered & $1(0.8)$ \\
\hline
\end{tabular}

The most frequent alterations in sports pre-participation assessments are increased blood pressure and ophthalmological problems. ${ }^{4}$ For this reason, Mirabelli et al. ${ }^{5}$ stated that this initial evaluation should assess at least the following parameters: vital signs, vision, hearing, and cardiovascular and musculoskeletal systems.

Pereira et al. ${ }^{14}$ demonstrated that athletes have better visual skills, especially in terms of peripheral visual acuity and visual field perception. In addition, the same authors showed that visual skills tend to improve with age, and that different sports positions do not necessarily require different levels of visual ability.

In a study by Sapkota et al., ${ }^{6}$ football and cricket players underwent ophthalmologic evaluation; the incidence of pinguecula and pterygium was $21 \%$. In the present study, pinguecula and pterygium were the most common conditions found in the biomicroscopy of the athletes, corresponding, to 63\% (38/60) and 17\% (10/60) of the alterations, respectively. In the same study by Sapkota et al., ${ }^{6} 69 \%$ of the athletes had never undergone an ophthalmological evaluation, and $3 \%$ of the athletes were colour blind. In the present study, $26.7 \%$ of the athletes
Table 2. Age of athletes according to results of visual acuity assessment ( $n=120)$.

\begin{tabular}{c|c|c|c|c}
\hline \multirow{2}{*}{ Age } & \multicolumn{2}{|c|}{ Visual Acuity - Right eye } & \multicolumn{2}{c}{ Visual Acuity - Left eye } \\
\cline { 2 - 5 } & Normal & Altered & Normal & Altered \\
\hline mean (SD) & $23.4(4.4)$ & $24.0(3.8)$ & $23.6(4.6)$ & $23.6(3.2)$ \\
\hline Minimum - maximum & $17-35$ & $19-31$ & $17-35$ & $19-31$ \\
\hline
\end{tabular}

Table 3. Fundoscopy and biomicroscopy, according to eye and position $(n=120)$.

\begin{tabular}{|c|c|c|c|c|c|}
\hline & \multicolumn{5}{|c|}{ Position } \\
\hline & Goalkeeper & Full-back & Defender & Midfielder & Forward \\
\hline \multicolumn{6}{|l|}{$\begin{array}{c}\text { Fundoscopy - } \\
\text { Right eye }\end{array}$} \\
\hline Normal & $11(78.6)$ & $11(68.8)$ & $18(72.0)$ & $33(71.7)$ & $18(94.7)$ \\
\hline Altered & $3(21.4)$ & $5(31.3)$ & $7(28.0)$ & $13(28.3)$ & $1(5.3)$ \\
\hline \multicolumn{6}{|l|}{$\begin{array}{l}\text { Fundoscopy } \\
\text { Left eye }\end{array}$} \\
\hline Normal & $11(78.6)$ & $11(68.8)$ & $18(72.0)$ & 33 (71.7) & 18 (94.7) \\
\hline Altered & $3(21.4)$ & $5(31.3)$ & $7(28.0)$ & $13(28.3)$ & $1(5.3)$ \\
\hline $\begin{array}{c}\text { Estimated } \\
\text { proportions }\left(\mathrm{Cl}_{95 \%}\right)\end{array}$ & $\begin{array}{c}24.9 \% \\
(0-55.1 \%) \\
\end{array}$ & \begin{tabular}{|c|}
$21.0 \%$ \\
$(0.7-41.3 \%)$ \\
\end{tabular} & \begin{tabular}{|c|}
$26.6 \%$ \\
$(6.2-46.9 \%)$ \\
\end{tabular} & \begin{tabular}{|c|}
$28.5 \%$ \\
$(12.8-44.2 \%)$ \\
\end{tabular} & \begin{tabular}{|c|}
$6.0 \%$ \\
$(0-17.4 \%)$ \\
\end{tabular} \\
\hline \multicolumn{6}{|l|}{$\begin{array}{c}\text { Biomicroscopy } \\
\text { Right eye }\end{array}$} \\
\hline Normal & $11(78.6)$ & $11(68.8)$ & $19(76.0)$ & $34(73.9)$ & $17(89.5)$ \\
\hline Altered & $3(21.4)$ & $5(31.3)$ & $6(24.0)$ & $12(26.1)$ & $2(10.5)$ \\
\hline \multicolumn{6}{|l|}{$\begin{array}{c}\text { Biomicroscopy } \\
\text { Left eye }\end{array}$} \\
\hline Normal & $10(71.4)$ & $10(62.5)$ & $18(72.0)$ & $33(71.7)$ & $17(89.5)$ \\
\hline Altered & $4(28.6)$ & $6(37.5)$ & $7(28.0)$ & $13(28.3)$ & $2(10.5)$ \\
\hline $\begin{array}{c}\text { Estimated } \\
\text { proportions }\left(\mathrm{Cl}_{95 \%}\right)\end{array}$ & $\begin{array}{c}16.2 \% \\
(0-36.9 \%)\end{array}$ & $\begin{array}{c}31.5 \% \\
(8.1-54.9 \%)\end{array}$ & $\begin{array}{c}31.7 \% \\
(12.8-50.5 \%)\end{array}$ & $\begin{array}{c}27.3 \% \\
(11.9-42.8 \%)\end{array}$ & $\begin{array}{c}12.2 \% \\
(0-28.0 \%)\end{array}$ \\
\hline
\end{tabular}

had never undergone an ophthalmological evaluation, and less than $1 \%$ of the athletes were colour blind. Sapkota et al. ${ }^{6}$ hypothesised that the high incidence of pinguecula and pterygium was due to prolonged exposure to sunlight, and we believe that this may be the cause of the high incidence of these alterations found in our study.

Despite the high prevalence of alterations found in the ophthalmologic evaluation, most refractive changes did not require correction (glasses/contact lenses), and the biomicroscopical alterations were mostly benign (pinguecula and pterygium).

One limitation of the study was that some data were retrospective and depended on the athletes' response/memory, which can be considered a bias. Another limitation is that the sample was composed of first division professional football players from Brazil, who normally have greater access to periodic medical and health assessments.

Annual ophthalmologic evaluation is recommended by medical ophthalmology societies. However, approximately a quarter of the assessed players had never undergone, or did not remember having undergone, an ophthalmic examination.

\section{CONCLUSION}

Despite the high prevalence of alterations found in ophthalmologic evaluation, most refractive changes did not require correction (glasses/ contact lenses), and the biomicroscopical alterations were mostly benign (pinguecula and pterygium).

\section{ACKNOWLEDGMENTS}

There has been no financial assistance with the project. We would like to thank the

Sports Department of Santos Futebol Clube for the support given to the development of this study.

All authors declare no potential conflict of interest related to this article 
AUTHORS' CONTRIBUTIONS: Each author made significant individual contributions to this manuscript. AST (0000-0002-1414-2822)*: writing, statistical analysis, intellectual concept, creation of the entire research project and execution; GGA (0000-0003-4371-5041)*: writing, statistical analysis, intellectual concept, creation of the entire research project; PHSL (0000-0002-1623-2071)*: statistical analysis and revision; RKZ (0000-0001-8001-3677)*, MC (0000-0001-7671-8113)* and BE (0000-0002-3301-1457)* writing, revision and intellectual concept. All authors approved the final version of the manuscript. *ORCID (Open Researcher and Contributor ID).

\section{REFERENCES}

1. Arliani GG, Lara PS, Astur DC, Cohen M, Gonçalves JP, Ferretti M. Impact of sports on health of former professional soccer players in Brazil. Acta Ortop Bras. 2014;22(4):188-90.

2. Junge A, Dvorak J. Soccer injuries: a review on incidence and prevention. Sports Med. 2004;34(13):929-38

3. Kramer EB, Dvorak J, Schmied C, Meyer T. F-MARC: promoting the prevention and management of sudden cardiac arrest in football. Br J Sports Med. 2015;49(9):597-8.

4. Lombardo JA, Badolato SK. The preparticipation physical examination. Clin Cornerstone. 2001;3(5):10-25.

5. Mirabelli MH, Devine MJ, Singh J, Mendoza M. The Preparticipation sports evaluation. Am Fam Physician. 2015;92(5):371-6.

6. Sapkota K, Koirala S, Shakya S, Chaudhary M, Paudel P. Visual status of Nepalese national football and cricket players. Nepal Med Coll J. 2006;8(4):280-3.

7. Wong HB, Machin D, Tan SB, Wong TY, Saw SM. Visual impairment and its impact on health-related quality of life in adolescents. Am J Ophthalmol. 2009;147(3):505-11.
8. Capao Filipe JA. Soccer (football) ocular injuries: an important eye health problem. Br J Ophthalmol. 2004;88(2):159-60

9. Laby DM, Kirschen DG. The refractive error of professional baseball players. Optom Vis Sci. 2017;94(5):564-73.

10. Mick TM, Dimeff RJ. What kind of physical examination does a young athlete need before participating in sports? Cleve Clin J Med. 2004;71(7):587-97.

11. Lehman PJ, Carl RL. The preparticipation physical evaluation. Pediatr Ann. 2017;46(3):e85-e92.

12. Miller DJ, Blum AB, Levine WN, Ahmad CS, Popkin CA. Preparticipation evaluation of the young athlete: what an orthopaedic surgeon needs to know. Am J Sports Med. 2016;44(6):1605-15.

13. Needleman I, Ashley P, Meehan L, Petrie A, Weiler R, McNally S, et al. Poor oral health including active caries in 187 UK professional male football players: clinical dental examination performed by dentists. Br J Sports Med. 2016;50(1):41-4.

14. Pereira VB, Pereira VB, Pereira RA, Kasahara N. Comparison of retinal sensitivity between professional soccer players and non-athletes. Int J Sports Med. 2016;37(4):282-7. 